\title{
Ortaokul Türkçe Dersi Öğretim Programlarında Sözlük Kullanma Alışkanlığı Kazandırmaya Dair Tespitler
}

\author{
Determinations about the Habit Use of Dictionary in \\ Secondary School Turkish Teaching Curriculums
}

\begin{abstract}
Sedat MADEN*, Recep DEMIR**
Öz: Bu çalışmada, ortaokul Türkçe dersi öğretim programlarının sözlük kullanma alışkanlığı kazandırmaya yönelik özelliklerinin tespit edilmesi amaçlanmaktadır. Bu çalışmada, nitel araştırma yaklaşımı benimsenmiştir. Cumhuriyetten günümüze kadar hazırlanan (1924-2018) ilköğretim ikinci kademe Türkçe dersi öğretim programlarında tespit edilen; sözlüğe yönlendiren, sözlük kullanmayı telkin ve teşvik eden kazanımlar ile çalışma sınırlandırılmıştır. Araştırma verilerinin toplanmasında doküman incelemesi tekniği kullanılmıştır. Çalışmanın veri kaynağı olan programlar, sözlük kullanma açısından ayrı ayrı incelenerek amaç ve açıklama ifadeleri tespit edilmiş, söz konusu olan program başlıklarına göre tasnif edilmiştir. Öğrencilerin sözlük kullanmasını doğrudan destekleyen ya da sözlük kullanmayı alışkanlık hâline getirilmesine katkıda bulunan ifadeler her programın ilgili bölüm başlığı altında toplanıp içerik analizine tabi tutulmuştur. Sözlük kullanmaya ilişkin ifadeler öğrenme alanı ve sınıf düzeyine göre değerlendirilerek yorumlanmıştır. Araştırma sonucunda, 1924 yılından bugüne her programda sözlük kullanmaya dair bir amaç ve uygulama açılamasının olduğu, ancak 2005 yılından sonraki programlarda daha ayrıntılı ve yoğun biçimde sözlük kullanmaya dair amaç ve açıklamaların bulunduğu tespit edilmiştir.
\end{abstract}

Anahtar Kelimeler: Sözlük, sözcük öğrenme, Türkçe öğretimi, program, alışkanlık

\begin{abstract}
In this study, it is aimed to determine the characteristics of secondary school Turkish teaching programs that direct them habit to use dictionary. In this research, qualitative research approach has been adopted. The study is limited with explanations, principles and target expressions which are detected in the second grade Turkish courses prepared from the Republic to the present day (1924-2018), conduct to the dictionary and suggest and encourage using dictionary. Document analysis technique has been used for collecting research data. The programs that are the data source of the study were examined separately for the use of dictionary and the purpose and explanation statements were determined and classified according to the program titles. Expressions that directly support the use of dictionaries by the students or that contribute to making the use of the dictionary a habit are gathered under the relevant section of each program and subjected to content analysis. Expressions related to the use of the dictionary were interpreted by evaluating according to the learning area and class level. As a result of this research, since 1924 , it has been determined that there is a purpose and application explanation for using dictionary in all programs. However, it is also noteworthy that the programs and intention to use dictionaries more intensively in the programs after 2005.
\end{abstract}

Keywords: Dictionary, word learning, Turkish teaching, curriculum, habit

\section{Giriş}

İnsanın duygu ve düşüncelerini ifade etmek için başvurduğu en etkili araç dildir. Dil vasıtasıyla, duygu ve düşünceleri tam olarak iletebilmek için ise yeterli ve doğru sözcüklere sahip olunması gerekir. Bu ihtiyaç, iletişim sürecinde kullanılacak sözcükleri muhafaza eden ve gerektiğinde kendisine başvurulan böylece yeni sözcüklerin öğrenilmesine hizmet eden bir kaynak olarak sözlüklerin işlev ve değerini belirler.

\footnotetext{
* Doç. Dr.,Giresun Üniversitesi Eğitim Fakültesi, Giresun-Türkiye, ORCID: 0000-0002-8024-8182, e-posta: sedat.maden@giresun.edu.tr

** Türkçe Öğretmeni, Avluca Şehit Ahmet Keskin Ortaokulu, Giresun-Türkiye, e-posta: recepdemirr28@ gmail.com
} 
Sözlük, Türkçe Sözlük’te "Bir dilin bütün veya belli bir çağda kullanılmış kelime ve deyimlerini alfabe sırasına göre alarak tanımlarını yapan, açıklayan, başka dillerdeki karşılıklarını veren eser, lügat." (Türk Dil Kurumu [TDK], 2009, s. 1806) şeklinde karşılık bulmaktadır. Vardar (2003, s. 183) ise sözlüğü, "Bir dildeki sözlüksel birimlerin tümünü ya da bir bölümünü, genellikle abecesel düzene, kimi durumlarda da konulara ya da kavramsal alanlara göre tanımları, tanıkları, söylenişleri, kökenleri, kullanımları, dilbilgisi ulamları, eşanlamlıları vb. ya da bir başka dildeki karşılıklarıyla sunan yapıt." olarak tanımlamaktadır. Korkmaz (2010, s. 199) da, "Bir dildeki kelimeleri esas alarak, onların temel anlamlarını, kazandıkları yan anlamlar ile başka kelimler ile kurdukları ifadelerdeki anlam inceliklerini, değişik kullanımlarını, deyimlerini gösteren ve o dilin bütün söz varlığını içine alan kitap.” olarak tarif eder.

Sözlükleri işledikleri ürünlerin kayıt durumuna, oluşturulduğu ortama, oluşturulma amacına ve yazılış biçimlerine bağlı olarak farklı şekillerde sınıflandırmak mümkündür (Aksan, 2007; Göçer, 2001; İlhan, 2009; Kocaman, 1998; Elbir ve Y1ldız, 2013). Sözlükler her yaştan insanın herhangi bir anlama ve anlatma ihtiyacı için gerekli olabilecek eserlerdir. Bu nedenle okul döneminde, özellikle dil öğretimi sürecinde, kullanımı ve bunun yerleşik alışkanlık hâlinde kazandırılması önem arz eder. Okul döneminde derslerde öğrencilerin ihtiyaçlarına cevap verebilecek sözlükler de bahsedilen sınıflandırma içinde okul sözlükleri adıyla yer almaktadır. Okul sözlükleri ile birlikte öğrencilerin gereksinimlerine cevap verebilecek genel, resimli sözlükler, yazar ve eser sözlükleri gibi farklı sözlüklerin de kullanılmasının söz konusu olabileceği de unutulmamalıdır.

Çocuk okul öncesi evrede ailesinden ve yakın çevresinden, gündelik yaşamda informal olarak öğrendiği sözcükleri okula başladığı andan itibaren yenileriyle birleştirerek söz varlığını geliştirir, bu süreçte sözlükten yararlanarak formal olarak yeni sözcükleri öğrenmeye başlar. Derslerde anlamadığı sözcükleri bağlamdan tahmin etmeye sonra da sözlüğe bakarak tahminlerini teyit etmeye çalışır. Böylece, günlük yaşamını ve anlam dünyasını zenginleştirebilmek için karşılaştı̆̆ 1 durumlara ilişkin yeni sözcükleri sözlükler aracılığıyla söz dağarcığına yerleştirmiş olurlar.

Söz dağarcığı, "Bir dilde kullanılan veya bir kimsenin bildiği, kullandığı sözlerin bütünü, söz varlığı, vokabüler, kelime hazinesidir" (TDK, 2009, s. 1805). Korkmaz (2010, s. 144) da söz dağarcığını "Bir dilin bütün kelimelerini; bir kişinin veya bir topluluğun söz dağarcı̆̆ında yer alan kelimeler toplamı.” şeklinde Türkçe Sözlük’teki (2009, s. 1130, 1805) gibi kelime hazinesi ile eş anlamlı olarak ve dilin bütün sözcüklerini içerdiğini ifade etmektedir. Vardar (2003, s. 182), "Bir bireyin kullandığı ya da bir bütüncede yer alan sözcüklerin tümü" şeklinde tanımlamıştır. Bu çalışmada da tanımların ortak görüşlerine bağlı olarak "bireyin kullandığı, bildiği, aktif ve pasif kelime hazinesinde yer alan sözcükler" bağlamında kullanılmıştır.

Gündelik hayatta insan merak ettiği, öğrenmek istediği ve bilme arzusundan kaynaklanan duygularla bilinçli ya da bilinçsiz yeni bir şeyler öğrenir. İnsan okul çağına geldiğinde, birtakım kurallara göre işleyen bir sosyal yapının parçası olur ve sosyal çevresine uyum sağlamak için eğitim alarak öğrenme ihtiyacını gidermeye çalışır. Öğrenirken de bazen anlam veremediği kavramlar karşısına çıkar. "İşte bu noktada hayatının her vaktinde elinin altında bulunacak, ona anlama konusunda rehber ve sözcüklerle ilgili problemlerine çözüm olacak başucu kaynağı şüphesiz sözlüklerdir. Sözlükler dil öğrenmenin en eski ve en önemli araçları arasında görülür. Bu nedenle, dil bilmek, sözcük bilmek ile eş değerde görülmüştür. Hatta dil öğrenen bireylere sözcük listeleri yani sözlükler ezberletilmiştir" (Baskın, 2017, s. 766-767). Bu tarihî gerçek, insanın sözcüklerle düşündüğüne dair yaygın kabule ek olarak sözlüğ̈̈n dil öğrenmenin de etkili bir aracı olduğunu da göstermektedir.

\section{Sözlük kullanmanın faydaları}

Ar1'ya (2006, s. 323) göre, sözcük öğretiminden önce sözlük kullanma öğrencilere öğretilmelidir. Çünkü "sözlük kullanmayı bilmeyen bir öğrenci için anlamı bilinmeyen sözcükler metni anlamanın önünde bir engel oluşturur" (Koyama ve Takeuchi, 2004'den akt. 
Melanlığlu, 2013, s. 268). İşte bu noktada ilköğretim için hazırlanan sözlükler, ilköğretim seviyesindeki öğrencilerin söz varlığını destekleyecek nitelikte olmalıdır. Türkçe eğitiminin de hedef kitlesini oluşturan ilköğretim birinci ve ikinci kademe öğrencilerinin söz varlığını geliştirmeye yönelik çalışmalar içinde sözlük kullanma alışkanlığının kazanılması öncelikli bir konudur. Sözlüklerde yer alan bütün sözcüklerin anlamın bilmek mümkün değildir. Öğrenciler, bir metni anlama çabası içine girdikleri zaman sözlükleri her zaman el altında bulundurmalıdır. Sözlük kullanma öğrencilere sözlü ve yazılı iletişimde ihtiyaç duyduğu ve bilmediği sözcüklerin anlamını öğrenmeyle beraber kendini güven içinde ifade, iletişim zorluklarını aşma, sözcüklerin günlük dilde hangi işlevde ve nasıl yer aldığını görme gibi çok yönlü faydalar sunar. Bu yararlar öğrencileri sözlük kullanmaya sevk etmekte ve bunun zamanla alışkanlığa dönüşmesini sağlamaktadır (Budak, 2000; Elbir ve Yıldız, 2013).

Öğrencilerin belirtildiği şekilde fayda sağlayabilmesi için sözlüklerin birtakım niteliklere sahip olması gerekmektedir. Göçer'e (2001, s. 400) göre ilköğretim seviyesine göre hazırlanmış sözlüklerin amaçlarını ve yararlarını şu şekilde sıralamak mümkündür:

- Öğrencilerin Türkçeyi daha iyi öğrenmesi, günlük hayatında doğru kullanmasına katkıda bulunmak.

- Özellikle ilkokulun ilk yıllarında öğrencilerin sözlük kullanmayı öğrenerek bir iş başarmanın sevincini tatmalarını sağlamak ve böylece öğrencilerde özgüven oluşturmak.

- Sözlük kullanma yeteneğinin bilgi edinmeye etkisini sezdirerek öğrencileri ders kitabı dışındaki yardımcı kaynak kitapların kullanımına alıştırmak ve özendirmek.

- Türkçe öğrenirken karşılaşılan zorlukların kolayca aşılmasını, öğrenilenleri doğru yerde kullanımını sağlamak.

- Kelimeleri örnek metinler içerisinde göstererek öğrencinin; şiir, hikâye, roman gibi türlerle Türk dilinin inceliğini ve etkileyici güzelliğini tanımasına yardımcı olmak.

- Öğrencileri karşılaştıkları problemleri çözebilecek yetkinliğe eriştirmek.

$\mathrm{Bu}$ amaçlara ulaşabilmek için ana dili öğretimi sürecinde öğrenci seviyesine ve gereksinimlerine uygun bir ortamın sağlanması gerekir. Diğer bir ifadeyle, sözlük kullanma becerilerini kazandırabilmek için öncelikle programlarda amacın ortaya konulması, öğrenmeögretme sürecinde bu kaynaktan nasıl yararlanılacağının açılanması ve bu konuda öğretmenlerin iyi yetiştirilmesi gibi önemli planlamalara ihtiyaç olduğu söylenebilir. Bu açıdan ülkemizde Türkçe dersi öğretim programlarının ve ders kitaplarının sözlük kullanımı açısından yeterli olması, öğretmenlerin de sözlükten yararlanmanın önemine dair farkındalığa ve yeterliliğe sahip olması beklenmelidir.

\section{Türkçe dersi ve sözlük kullanma}

Dil eğitimi, dinlediklerini veya okuduklarını tam ve eksiksiz anlayabilen, kendini konuşarak veya yazarak doğru ve etkili biçimde ifade edebilen bireyler yetiştirmeyi hedeflemektedir. "Temel dil becerilerinin doğru ve etkili biçimde kazandırılabilmesi için öğrencilerin sözcük bilgisinin belli bir seviyeye gelmiş olması lazımdır." (Süt, 2015, s. 57). Öğrencilerin sözcük bilgisini geliştirmek ve zenginleştirmek için ise, okul öncesi evrede aile ve yakın çevreden edinilmiş olan söz varlığının okulda Türkçe derslerinde sistemli biçimde örnek iletişim durumlarına bağlı olarak artırılması ile mümkün olabilir. Türkçe derslerinde sözcük öğretimine ilişkin planlama içerisinde sözlükten yararlanma becerilerini kazandırma hayati öneme sahiptir. $\mathrm{Bu}$ alışkanlık sadece okuldaki başarıda değil daha sonraki yaşamında da bireyin anlama ve anlatma düzeyini belirler. Diğer bir deyişle, gerek öğrenciliğinde gerekse yetişkinliğinde bireylerin okudukları metinleri, dinledikleri konuşmaları tam ve doğru bir şekilde anlamaları ayrıca anladıkları ile ilgili düşüncelerini anlatabilmeleri için sözcükler anahtar bir rol üstlenmektedir. 
Sözlük kullanma alışkanlığı kazanan bireylerin sözcük hazineleri zenginleşir. Sözcük hazinesi zenginleşen birey sözlü ve yazılı iletişim sürecinde kendini daha iyi ifade eder. Dolayısıyla, sözcük hazinesinin gelişmesi ile öğrenciler, bir metni okurken ya da birini dinlerken daha iyi anlayacak, kendisini sözle veya yazıyla daha iyi anlatacaktır. Türkçe derslerinde yapılan okuma çalışmalarında metin içindeki bilinmeyen sözcükleri öğrenmek için sözlüğe ihtiyaç vardır.

Sözcük hazinesi, "bireyin öğrenme süreci sonucunda zihinde depolanan birikimi ifade eder. $\mathrm{Bu}$ birikimi en etkili şekilde artırma ve kullanmayı sağlayacak ortam, okul ortamı ve özellikle Türkçe dersleridir. Bu derste sözcük dağarcığını zenginleştirme çalışmaları ile öğrencinin hem dili iyi derecede kullanması hem de düşünce dünyasını geliştirmesi sağlanır" (Özbay ve Melanlığlu, 2008, s. 33). Sözcük hazinesinin geliştirilmesi, Türkçe derslerindeki okuma ve anlama çalışmalarında temeli atılan bir özellik taşımaktadır. Çocuk bu temel üzerine anlama becerisini kurar ve geliştirir. Zira söylenenlerle birlikte bilhassa okuduğunu anlama tüm alanlardaki akademik bașarıda belirleyicidir. Okuduğunu anlayamamanın "nedenlerinden biri de sözcük dağarcığının sınırlı oluşudur" (Özbek ve Ergül, 2018, s. 654). Çocuklarımızın sözcük hazinesini geliştirmenin en etkili yolu şüphesiz onlara okuma alışkanlığı kazandırmak, ayrıca okurken başvuru eseri olarak sözlüklere başvurmayı doğal bir gereksinim hâline getirmektir. Nitekim sözcük hazinesi ile okuma arasında birbirini bütünleyen bir bağ vardır. Okunan metnin ne düzeyde anlaşılacağı sözcük hazinesinin zenginliğine bağlıdır. Bu durum dinleme, konuşma ve yazmadaki başarı için de geçerlidir.

\section{Araştırmanın amacı}

Ana dili eğitiminin genel çerçevesini çizen Türkçe dersi öğretim programları dilin bilinç düzeyinde öğretilmesini sağlar. Sözcük hazinesinin geliştirilmesi de bu çerçevenin en önemli parçalarından biridir. Dili oluşturan sözcüklerin yer aldığı sözlükler vasıtasıyla öğrenciler kendilerini hayata hazırlamakta, bilgi seviyesini yükseltmekte, toplumun kültürünü kazanmakta ve bir sonraki eğitim düzeyine devam etmektedir.

Melanlığlu (2013) literatürde, öğrencilerin sözlük kullanma alışkanlıkları ya da buna dair ihtiyaçlarını belirlemeye yönelik çalışmaların oldukça sınırlı olduğunu ifade etmiştir. Diğer taraftan Maden ve Maden (2018) de hem basılı hem de elektronik sözlük kullanımının sözcük hazinesini geliştirme ve okuma becerisine etkisi ile tutum ve alışkanlık boyutlarının çeşitli araştırmalarda incelendiğini belirtmektedir (Boz ve Demirtaş, 2011; Can ve Deniz, 2016; Dağtaş, 2014; İbe Akcan, 2012; Kolaç, 2009; Özbay ve Melanlığlu,2013; Yaman ve Dağtaş, 2010). Buna karşın sözlük kullanma alışkanlığının kazandırılmasına yönelik öğretim sürecini de planlayan Türkçe dersi öğretim programlarının bu açıdan değerlendirilmemiş olduğu görülmektedir.

Söz konusu tespitlerden yola çıkarak araştırmada, ortaokul Türkçe dersi öğretim programlarının sözlük kullanma alışkanlığına yönelik özelliklerinin incelenmesi amaçlanmıştır. $\mathrm{Bu}$ amaçla ulaşılacak sonuçların konuyla ilgili var olan durumun analizinde fayda sağlayacağ öngörülmektedir. Böylece sözlük kullanma alışkanlığının programlı biçimde nasıl kazandırılmaya çalışıldığını kronolojik olarak görmek ve değerlendirmek, bu açıdan nasıl bir gelişim ve değişim içinde olunduğunu gözler önüne sermek ve konuyla ilgili yapılacak olan çalışmalara yol göstermek gibi katkılar sunulabilecektir.

\section{Yöntem}

$\mathrm{Bu}$ çalışmada, nitel araştırma yaklaşımı benimsenmiştir. Nitel araştırmalarda veriler teker teker okunur, kod ve kategorilere ayrılır ve bu şekilde araştırma sonuçlarının sunulması sağlanır (Merriam, 1998, s. 58). Ayrıca bu desende, araştırılacak konu ya da konular doğal ortamlarında gerçekçi ve bütüncül biçimde anlamlandırılmaya ve yorumlanmaya çalışılır (Ekiz, 2009, s. 31). 


\section{Sinırlılıklar}

Cumhuriyetten günümüze kadar hazırlanan ilköğretim ikinci kademe Türkçe dersi öğretim programlarında tespit edilen; sözlüğe yönlendiren, sözlük kullanmayı telkin ve teşvik eden açıklama ve amaç ifadeleri ile çalışma sınırlandırılmıştır.

\section{Veri kaynă̆ı}

Çalışmanın veri kaynağını 1924 yılından bugüne kadar uygulamaya konulmuş olan ortaokul Türkçe dersi öğretim programları oluşturmaktadır. Veri kaynağındaki program metinleri basılı ve elektronik ortamda edinilerek doküman incelemesi yöntemiyle taranmış ve sözlük kullanımına ilişkin bulgular tespit edilmiştir. Veri kaynăg 1 içerisindeki 1924'ten 1981 programına kadar olan ortaokul Türkçe programlanına ait incelemeler için Temizyürek ve Balcı'nın (2006) Cumhuriyet Dönemi İlkögretim Okulları Türkçe Programları adlı çalışması esas alınmıştır. Daha sonraki yıllarda uygulamaya konulan programlar için Millî Eğitim Bakanlığının yayınladı̆̆ı program metinlerinden yararlanılmıştır. Bu doğrultuda araştırmada incelenen veri kaynakları şu şekildedir:

Temizyürek, F. ve Balcı, A. (2006). Cumhuriyet dönemi ilköğretim okulları Türkçe programlarl. Ankara: Nobel Yayınları

Millî Eğitim Bakanlığı (2006). İlköğretim Türkçe dersi öğretim programı (6-8. Sinıflar). Ankara: Devlet Kitapları Müdürlüğü.

Millî Eğitim Bakanlığı (2015). Türkçe Dersi (1-8.sinıflar) Öğretim Programı. Ankara.

Millî Eğitim Bakanlığı (2017). Türkçe Dersi Öğretim Programı (İlkokul ve ortaokul 18.siniflar). Ankara.

Millî Eğitim Bakanlığı (2018). Türkçe Dersi Öğretim Programı (Illkokul ve ortaokul 1 8.siniflar). Ankara.

\section{Verilerin toplanması ve analizi}

Araştırma verilerinin toplanması ve analizinde, doküman incelemesi tekniği kullanılmıştır. Doküman incelemesi, "araştırılan olgu ve olgular hakkında bilgi içeren yazılı materyallerin analizini ifade eder. Nitel araştırmada doküman incelemesi tek başına bir veri toplama yöntemi olabileceği gibi diğer veri toplama yöntemleri ile birlikte de kullanılır" (Yıldırım ve Şimşek, 2013, s. 217). Çalışmanın veri kaynağı olan programlar, sözlük kullanma açısından ayrı ayrı incelenerek amaç ve açıklama ifadeleri tespit edilmiş, söz konusu program adlarına göre tasnif edilmiştir.

Öğrencilerin sözlük kullanmasını doğrudan destekleyen ya da sözlük kullanmanın alışkanlık hâline getirilmesine katkıda bulunan ifadeler her programın ilgili bölüm başlığ altında toplanıp içerik analizine tabi tutulmuştur. Sözlük kullanmaya ilişkin ifadeler öğrenme alanı ve sınıf düzeyine göre değerlendirilerek yorumlanmıştır.

\section{Bulgular ve Yorum}

Çalışmanın bu bölümünde, 1924 Lise Birinci Devre Müfredat Programı'ndan en son uygulamaya konulan 2018 Türkçe Dersi Öğretim Programı'na kadarki ortaokul programlarındaki sözlük kullanımına dair amaç ve açıklamalar belirlenmiş; tespit edilen bulgular ayrı başlıklar altında yorumlanarak aktarılmıştır.

\section{Ortaokul Türkçe dersi öğretim programlarında sözlük kullanımı 1924 lise birinci devre müfredat programı}

1924 yılında ortaokullar ortaöğretim kurumlarının birinci devresi olarak yapılandırılmıştı. Bu nedenle, Türkçe öğretimi için hazırlanmış olan programda lise birinci devre adını taşımaktadır. Söz konusu program sözlük kullanımı açısından değerlendirildiğinde, doğrudan sözlük kullanma becerisine yönelik herhangi bir hedef ve açıklamanın olmadığı tespit edilmiştir. 


\section{9 ortamektep Türkçe programı}

Tablo 1.

1929 Ortaokul Programındaki Sözlük Kullanımına Dair Tespitler

\begin{tabular}{lrl}
\hline Bölüm/Alan & Sınıf & İfade \\
\hline Edebî Kıraat & - & $\begin{array}{l}\text { Muallim talebeyi bir kelimenin manasını lügatlerde süratle } \\
\text { bulmağa alıştırmalı ve derslerde s1k sık lügatlerden kelime bulma } \\
\text { temrinleri yaptırmalıdır. (18. Madde) }\end{array}$ \\
\hline
\end{tabular}

1929 Ortamektep programında, sadece edebî derslerinin işlenişine dair esaslar içerisinde öğrencilerin bir sözcüğün anlamını sözlükten bulmaya alıştırılması ve bunun için sıklıkla alıştırmalara başvurulması istenilmektedir. $\mathrm{Bu}$ bulgu programda sözlük kullanmanın öğrencilerin kolayca yapabilecekleri bir alışkanlığa dönüştürülmesinin hedeflendiğini göstermektedir.

\section{1-1932 ders senesi tadilatı Türkçe programı}

Tablo 2.

1931-1932 Ortaokul Programındaki Sözlük Kullanımına Dair Tespitler

\begin{tabular}{|c|c|c|}
\hline Bölüm /Alan & Sinif & İfade \\
\hline Edebî Kıraat & & $\begin{array}{l}\text { Muallim talebeyi bir kelimenin manasını lügatlerde süratle } \\
\text { bulmağa alıştırmalı ve derslerde sik sik lügatlerden kelime } \\
\text { bulma temrinleri yaptırmalıdır. (18. Madde) }\end{array}$ \\
\hline
\end{tabular}

1931-1932 tadilatı programında, 1929 programındaki esas açıklaması aynen korunmuştur.

\section{8 ortaokul türkçe programı}

Tablo 3.

1938 Ortaokul Programındaki Sözlük Kullanımına Dair Tespitler

\begin{tabular}{lll}
\hline Bölüm/Alan & Sınıf & İfade \\
\hline Okuma & - & $\begin{array}{l}\text { Muallim talebeyi bir kelimenin manasını lügatlerde süratle bulmağa } \\
\text { alıştırmalı ve derslerde sık sik lügatlerden kelime bulma temrinleri } \\
\text { yaptırmalıdır. (18. Madde) }\end{array}$ \\
\hline
\end{tabular}

1938 programında da 1929 ve 1931-32 programlarındaki açıklama aynen sürdürülmüştür. $\mathrm{Bu}$ üç programda öğrenci bilmediği sözcüklerin anlamını öğrenmek için sözlüğe bakmalı ve sürekli bu işlemi tekrarlamalıdır. Böylece, sözlük kullanmanın öğrencilerde ihtiyaç duyuldukça yapılabilecek bir alışkanlığa dönüşmesi hedeflenmektedir.

\section{Ortaokul Türkçe Programı}

Tablo 4.

1949 Ortaokul Programındaki Sözlük Kullanımına Dair Tespitler Bölüm /Alan Sınıf İfade

\begin{tabular}{cl}
\hline $\begin{array}{c}\text { Okuma } \\
\text { Açıklamalar }\end{array}$ & $-\begin{array}{l}\text { Ilkokulun okuma amaçları arasında istenen fihrist, indeks, harita, resim, } \\
\text { plan, sözlük, imla kılavuzu ve ansiklopedilerden faydalanmak... (3. Madde) }\end{array}$ \\
\hline $\begin{array}{c}\text { İmlâ } \\
\text { Açılamalar }\end{array}$ & $\begin{array}{l}\text { Ortaokulda imlâ ve mânası yeni ögrenilen kelimeler için bir lügat defteri } \\
\text { tutmanın veya ilk okuldaki kelime defterini bu maksatla devam ettirmenin } \\
\text { de uygun olacağı söylenebilir. (d-Maddesi) }\end{array}$ \\
\hline İmlât & $\begin{array}{l}\text { Düzeltmelerde esas kaynaklar, Türkçe Sözlük ve İmlâ Kılavuzudur. (d- } \\
\text { Açıklamalar }\end{array}$ \\
\hline
\end{tabular}


1949 programında, önceki programlardan farklı olarak sözlüğün yanı sıra imlâ kılavuzu, ansiklopedi, fihrist, indeks gibi sözlük kullanımı ile ilişkili kaynakların kullanımından da bahsedilmiştir. Okuma alanı ile ilgili açıklamalarda, farklı türde kaynakları okurken bu kaynaklardan daha etkili ve tam manasıyla yararlanabilmek için fihrist, dizin, plan, harita gibi bölümlerinin tanınması, ayrıca sözlük ve ansiklopedi gibi temel kaynaklara da okunan eseri anlamada başvurulması hedeflenmiştir. Yine imla açıklamalarında, yeni öğrenilen sözcükler için bir lügat defterinin oluşturulması, hatta ilkokulda bu defter uygulamasına başlanması ve ortaokulda sürdürülmesi istenilmiştir. Programda sözlügün kullanımının okuma ve yazılı anlatım sürecinde önemsediğine dair anılan hususların yanında öğrenci anlatımında düzeltme için başvurulacak temel kaynak olarak sunulması da önemli bir durumdur.

\section{2 ortaokul Türkçe programı}

Tablo 5.

1962 Ortaokul Programındaki Sözlük Kullanımına Dair Tespitler

\begin{tabular}{ccl}
\hline Bölüm /Alan & Sınıf & İfade \\
\hline $\begin{array}{c}\text { Okuma } \\
\text { Açılamalar }\end{array}$ & - & $\begin{array}{l}\text { Illkokulun okuma amaçları arasında istenen fihrist, indeks, harita, } \\
\text { resim, plân, sözlük, imlâ kılavuzu ve ansiklopedilerden } \\
\text { faydalanmak;... (3. Madde) }\end{array}$ \\
\hline $\begin{array}{c}\text { İmlâ } \\
\text { Açıklamalar }\end{array}$ & $-\begin{array}{l}\text { Ortaokulda imla ve anlamı yeni öğrenilen sözcükler için bir sözlük } \\
\text { defteri tutturmanın veya ilkokuldaki sözcük defterini bu amaçla } \\
\text { devam ettirmenin de uygun olacağı söylenebilir. (d-Maddesi) }\end{array}$ \\
\hline $\begin{array}{c}\text { İmlâ } \\
\text { Açıklamalar }\end{array}$ & - & $\begin{array}{l}\text { Düzeltmelerde temek kaynaklar, Türkçe Sözlük ve İmlâ Kilavuzudur. } \\
\text { (d-Maddesi) }\end{array}$ \\
\hline
\end{tabular}

1962 ortaokul programında ilkokulun okuma amaçları arasında geçen okunulan bir metni daha iyi anlayabilmek için başvurulabilecek kaynaklar arasında sözlüğe yer verilmesi dikkat çekmektedir. Bu açıklama, sözlüğün ve diğer başvuru eserlerinin okuma sürecindeki öneminin fark edildiğini ve sözlüğün bir metni anlamadaki yerini öğrencilere göstermektedir. Ayrıca, ilkokulda tutulmaya başlanan sözcük defteri uygulamasına ortaokulda devam edilmesi öğrenciye sözlük kullanma alışkanlığı kazandırmak için planlanmış uygulamaların en somut örneğidir. Yine sadece okuduğunu anlamada değil yazılı anlatım sürecinde de sözcüklerin doğru yazılışlarına vurgu yapılmış ve bunun için sözlük ve imlâ kılavuzu kullanımının gerektiği gösterilmiştir.

1962 yılı programı da dâhil olmak üzere, ortaokullarda sözlük kullanmayı bir alışkanlık haline getirmeye yönelik sözcük defteri uygulamasının dışında kapsamlı ve süreklilik arz eden bir hedef-davranış örüntüsüne veya ders içi-dışı bir uygulama planına rastlanamamaktadır.

\section{1 temel eğitim okulları Türkçe eğitim programı}

Tablo 6.

1981 Ortaokul Programındaki Sözlük Kullanımına Dair Tespitler

\begin{tabular}{|c|c|c|}
\hline Bölüm/Alan & Sinif & İfade \\
\hline $\begin{array}{c}\text { Anlama } \\
\text { Özel Amaçlar }\end{array}$ & $6-8$ & $\begin{array}{l}\text { Öğrencilere dipnot, dizin, sözlük, ansiklopedi her türlü başvurma } \\
\text { ve kaynak eserlerden yararlanma yeteneğini kazandırıp geliştirmek. } \\
\text { (4. Madde) }\end{array}$ \\
\hline Okuma & 6 & $\begin{array}{l}\text { Kitaplardaki içindekiler, dizin } \\
\text { yararlanabilmek (3. Madde) }\end{array}$ \\
\hline Okuma & 6 & $\begin{array}{l}\text { Yazım kılavuzundan, sözlüklerden, ansiklopedilerden ve kaynak } \\
\text { kitaplardan yararlanabilmek. (4. Madde) }\end{array}$ \\
\hline $\begin{array}{c}\text { Dilbilgisi } \\
\text { Öğrenciye } \\
\text { Kazandırılacak }\end{array}$ & 6 & Türkçe Sözlük”e ve yazım kılavuzuna başvurabilmek. (19. Madde) \\
\hline
\end{tabular}




\begin{tabular}{|c|c|c|}
\hline \multicolumn{3}{|l|}{ Davranışlar } \\
\hline Okuma & 7 & $\begin{array}{lcccc}\text { Kitaplardaki içindekiler, dizin } & \text { ve } & \text { sözlük } & \text { bölümlerinden } \\
\text { yararlanabilmek (3. Madde) }\end{array}$ \\
\hline Okuma & 7 & $\begin{array}{l}\text { Yazım k1lavuzundan, sözlüklerden, ansiklopedilerden ve kaynak } \\
\text { kitaplardan yararlanabilmek. (4. Madde) }\end{array}$ \\
\hline $\begin{array}{c}\text { Dilbilgisi } \\
\text { Öğrenciye } \\
\text { Kazandırılacak } \\
\text { Davranışlar }\end{array}$ & 7 & Türkçe Sözlük’e ve yazım kılavuzuna başvurabilmek. (16. Madde) \\
\hline Okuma & 8 & $\begin{array}{l}\text { Kitaplardaki içindekiler, ön söz, dipnot, atıf, dizin ve sözlüklerden } \\
\text { yararlanabilmek. (3. Madde) }\end{array}$ \\
\hline Okuma & 8 & $\begin{array}{l}\text { Yazım kılavuzundan, sözlüklerden, ansiklopedilerden ve kaynak } \\
\text { kitaplardan yararlanabilmek;... ( } 4 \text {. Madde) }\end{array}$ \\
\hline $\begin{array}{c}\text { Dilbilgisi } \\
\text { Öğrenciye } \\
\text { Kazandırılacak } \\
\text { Davranışlar }\end{array}$ & 8 & $\begin{array}{l}\text { Türkçe Sözlük'e ve yazım kılavuzuna vb. ne başvurabilmek. (16. } \\
\text { Madde) }\end{array}$ \\
\hline $\begin{array}{c}\text { Sözcük } \\
\text { Çalışması }\end{array}$ & 6,7 ve 8 & $\begin{array}{l}\text { Öğrenciden, henüz metinle karşllaşmadan, yani metni dinleyip } \\
\text { okumadan önce, ev çalışması olarak sözcüklerin, deyimlerin, } \\
\text { deyişlerin, terimlerin anlamlarını sözlüklerden bulup yazmaları, } \\
\text { ezberlemeleri istenmemelidir. Hele sözcüğ̈̈n metin içindeki anlamı } \\
\text { iyice kavranılmadan, öğrenilmeden cümlede kullanma çalışmaları } \\
\text { yaptırmak, tüm olarak ezbercilik demektir; bu, öğrenciye bir şey } \\
\text { kazandırmadığı gibi zamanın boşa gitmesine yol açar; daha kötüsü } \\
\text { öğrencinin Türkçe dersinden soğumasına neden olur ve okuma, } \\
\text { sözlük çalışması gibi en değerli öğrenme araçlarını benimseyerek } \\
\text { onlardan yararlanma imkânlarını ortadan kaldırır. İnceleme } \\
\text { sırasında, metnin düşünce yapısını oluşturan sözcüklerin ası } \\
\text { anlamının sözün gelişinden eksiksiz ve iyi anlaşılmadığ1 } \\
\text { durumlarda sözlük, ansiklopedi, dipnotlar, dizin, atıf ve başka } \\
\text { kaynak eserlerden yararlanma yoluna gidilmelidir.... (Ç-Maddesi) }\end{array}$ \\
\hline
\end{tabular}

1981 programı hem ilkokul hem ortaokul düzeyine yönelik bölümleri tek çatı altında toplamış ve kendisinden önceki programlardan daha ayrıntılı biçimde hazırlanmıştır. Öğrenciye kazandırılacak davranışlar, açıklamalar ve okuma kazanımı bölümlerinde öğrenciyi sözlük kullanmaya yönlendirmeye dair kısımlar yer almaktadır. Bu kapsamda anlama becerilerine yönelik özel amaçlar içerisinde sözlük ve benzeri türde kaynaklardan yararlanma yeteneği kazandırma ve bunun geliştirilmesinin planlanmış olması, bir alışkanlık olmasına da çalışıldığını ifade etmektedir. Ayrıca okuma becerisi ile ilgili davranışlar arasında da 6,7 ve 8 . Sınıf düzeyinde devam eden hedeflerin de belirlendiği görülmektedir. Bu davranışlar öğrencilerin okuma etkinliklerinde sözlük kullanmaya alışmasını ve bunu öğretim süreci boyunca devam ettirerek yerleşik hâle getirmeye hizmet etmektedir. Okunan ya da dinlenilen kitap, metin ve sözlü ifadenin daha iyi anlaşılabilmesi için dikkat edilecek ve başvurulabilecek içindekiler, dizin, ansiklopedi gibi araç ve kaynakların sözlük ile birlikte kullandırılması bilgiye ulaşma sürecinde bu tür araçların amacını ve önemini fark ettirmektedir. Her sınıf düzeyinde sözlükten sadece sözcüğün anlamını öğrenmede değil, yazılışı ve dil bilgisel özellikleri için de yararlanılabileceğini göstermek amacıyla dil bilgisi bölümündeki davranışlar arasında yazım kılavuzu ile birlikte kullanımının planlanması dikkat çekmektedir. Okuma ve dil bilgisi alanları dıșındaki dil becerilerine dair açıklama ve davranıșlar içerisinde sözlük kullanımı ile ilgili bir planlamanın olmaması bir eksiklik olarak görülebilir. Yöntem bölümünde okuma metni ile ilgili sözcük çalışmaları başlığı altında, sözcük öğretimine izlenecek yol açıklanırken öğrencinin okunacak metinde karşılaştığı sözcükleri metnin bağlamı içinde kavramadan sözlüğe 
başvurmaması aksi takdirde ezberciliğe yönlendirilmiş olacağı şeklinde bir ikazın olması önemli bir bulgudur. $\mathrm{Bu}$ nedenle programda sözcük çalışması başlı̆̆ında; metni okumadan öğrencinin bilmediği sözcüklere sözlüklerden bakmaması, cümle kurulmaması ve ödev olarak bu sözcüklerin verilmemesi gerektiği vurgulanmaktadır. Çünkü öğrenciyi kolaycıllğa ve ezberciliğe sevk edeceğinden olumsuz bir durumdur. Öğrenci sözcüğg̈ kavradıktan sonra ona ödev verilebileceğini de ifade edilmektedir. Sözcük öğretimine dair bu bakış açısı, sözcüklerin anlamının kalıcı biçimde öğrenilmesine ve sözlük kullanımının da bu süreçte önem arz ettiğine işaret etmektedir.

\section{6 ilköğretim $(6,7,8$. Sınıflar) Türkçe dersi öğretim programı}

2005 ilkokul programında benimsenen yapılandırmacı eğitim anlayışı bu programın da temelini oluşturmaktadır. Programda, öğrenme sürecinde öğrencinin birikim ve deneyimlerinden hareket ederek, gelişim düzeyi dikkate alınarak, aktif katılım ve iş birliğine önem verilerek öğrendiklerini aşamalı bir biçimde inşa etmesi önemsenmiştir. Buna bağlı olarak, Türkçe dersinde dil becerilerinin doğru ve etkili kullanımının alışkanlıklara dönüştürülerek öğrenciyi hayata hazırlamak amaçlanmıştır. İlkokul programında olduğunu gibi yapılandırmacıllı̆ının yanında açıkça ifade edilmezse de öğrenci merkezli çoklu zekâ, etkinlik temelli öğrenme, sarmallık, tematik yaklaşım, aktif ve iş birlikli öğrenme ilkeleri de dikkate alınmıştır. Programda öğrenme alanları dinleme/izleme, konuşma, okuma, yazma ve dil bilgisi şeklinde düzenlenmiştir. Programdaki anlamaya yönelik dinleme / izleme ve okuma alanı ile ilgili kazanım, kazanım açıklamaları ve etkinlik önerileri sözlük kullanımının birer alışkanlığa dönüştürülmeye çalışıldığına işaret etmektedir. Ayrıca programın sonunda verilen sözlük de bu açıdan önemlidir. Ancak söz konusu sözlük, elli iki (52) sözcük ve sözcük öbeği içermektedir. Sözlük daha da geniş̧letilmesi önerilebilir, yine de programın uygulayıcısı olan öğretmenlere yol göstereceği bu açıdan faydalı olduğu söylenebilir.

Tablo 7.

2006 Ortaokul Programındaki Sözlük Kullanımına Dair Tespitler

\begin{tabular}{|c|c|c|}
\hline Bölüm /Alan & Sinif & Kazanım ifadesi \\
\hline Dinleme/İzleme & 6,7 ve 8 & $\begin{array}{l}\text { Dinlenenin/izlenenin bağlamından hareketle sözcük ve sözcük } \\
\text { gruplarının anlamını çıkarır. } \\
\text { Açıklama: Öğrenciler tahminlerinin doğruluğunu kontrol } \\
\text { etmek amacıyla sözlük kullanmaya yönlendirilir. ... }\end{array}$ \\
\hline Dinleme/İzleme & 6,7 ve 8 & $\begin{array}{l}\text { Aynı kavram alanına giren sözcükleri, anlam farklılıklarını } \\
\text { dikkate alarak kullanır. } \\
\text { Açıklama: Söz varlığını zenginleştirme çalışmalarında Türkçe } \\
\text { Sözlük, atasözleri ve deyimler sözlüğü, terimler sözlüğü, } \\
\text { ansiklopedik sözlük vb. den yararlanılır. }\end{array}$ \\
\hline Dinleme/İzleme & 6,7 ve 8 & $\begin{array}{l}\text { Dinlediklerinden/izlediklerinden hareketle yeni öğrendiği } \\
\text { sözcüklerden sözlük oluşturur. } \\
\text { Etkinlik: "Sözlük Oluşturuyorum". İsim ve fiillerden sözlük } \\
\text { oluşturulur. }\end{array}$ \\
\hline Okuma & 6,7 ve 8 & $\begin{array}{l}\text { Metnin bağlamından hareketle sözcük ve sözcük gruplarının } \\
\text { anlamlarını çıkarır. } \\
\text { Açıklama: Öğrenciler tahminlerinin doğruluğunu kontrol } \\
\text { etmek amacıyla sözlük kullanmaya yönlendirilir.... }\end{array}$ \\
\hline Okuma & 6,7 ve 8 & $\begin{array}{l}\text { Aynı kavram alanına giren sözcükleri, anlam farklılıklarını } \\
\text { dikkate alarak kullanır. } \\
\text { Açıklama: Söz varlığını zenginleştirme çalışmalarında Türkçe } \\
\text { Sözlük, atasözleri ve deyimler sözlüğü, terimler sözlüğü, } \\
\text { ansiklopedik sözlük vb. den yararlanılır. }\end{array}$ \\
\hline Okuma & 6,7 ve 8 & $\begin{array}{l}\text { Okuduklarından hareketle öğrendiği sözcüklerden sözlük } \\
\text { olușturur. }\end{array}$ \\
\hline
\end{tabular}


Tabloda görüldüğü üzere, dinleme / izleme ve okuma becerileri için belirlenmiș Söz Varlı̆̆ını Zenginleştirme amacına bağlı kazanımlar arasında sözlük kullanma alışkanlığ kazandırmaya yönelik kazanımlara ve açıklamalara yer verilmiştir.

Kazanımlar incelendiğinde sözcüklerin metin / bağlam içinde anlamlarını öğrenmeye, sözcükleri farklı anlamları ile kullanmaya ve öğrenilen sözcüklerden sözlük oluşturmaya önem verildiği görülmektedir. Bu etkinlik önceki programlarda yer alan sözcük defteri uygulamasının bir devamı olarak görülebilir. Ancak defterden sözlüğe yaşanan değişiklik sözlüğün artık bir kaynak olarak görüldüğü ve onu kullanmanın da bu kaynağın oluşumunu tanıyarak gerçekleşebileceği şeklinde değerlendirilebilir.

Sözcüklerin anlamlarının bağlamdan hareketle öğrenilmesi, tahmine önem verilmesi de ön bilgilerden hareket ilkesi ile yapılandırmacılığı çağrıştırmaktadır. Bununla birlikte sözlük kullanmaya yönlendiren kazanımların öğretiminde yararlanılabilecek öğrenme etkinliği örneklerinin sunulması ve bunlara dair açıklamaların da verilmesi de bu becerilerin birer alışkanlığa dönüştürülmeye çalışıldığını göstermektedir. Diğer taraftan sözcük öğretimi sürecinde sözlük kullanma becerilerinin kalıcı biçimde kazandırılması için ciddi bir planlamanın yapıldığını da göstermektedir. Bu özellikleri ile programın daha önceki programlarda yer verilen sözcük defteri oluşturma ve sözlük oluşturma uygulamalarına yer vererek sözlük kullanma açısından bir devamlılık oluşturduğu belirtilmelidir.

Türkçe Sözlük dışında atasözleri ve deyimler sözlügü, terimler sözlüğü, ansiklopedik sözlüklerden de yararlanılmasının istenilmesi öğrenciyi daha fazla kaynağa yönlendirerek ögrenmede alternatif yollara da sevk etmektedir.

\section{Türkçe dersi (1-8. sınıflar) öğretim programı}

2015 y1lında ilkokul ve ortaokuldaki Türkçe öğretimini tek çatı altında ele alan yeni program dil becerilerini hayat boyu öğrenmedeki yeri ve dijital ortamlardaki kullanım alanlarını dikkate alarak sözlük iletişim, okuma ve yazma alanlarında geliştirmeyi hedeflemiştir. Programın söz varlığını zenginleştirmeye dil zevki kazanma, dil bilincine ulaşma ve duygu, düşünce ve hayal dünyasını geliştirme açısından yaklaştığı da genel amaçlarından anlaşılmaktadır. Ayrıca bilgiye erişme, kullanma ve üretmede dil becerilerinin hem basılı hem elektronik araçlar/ortamlar üzerinde kullanımını da önemsediği amaçları arasında görülmektedir. Bu durum, 2005 yılından bu yana Türkçe öğretim programlarında bilgiye ulaşma ve teknolojiden yararlanmaya dair var olan yaklaşım açısından bir devamlılığın söz konusu olduğunu da göstermektedir. 2015 programı ile ilgili bu özellikler, hem söz varlığını zenginleştirme hem de bilgiye ulaşma açısından basılı ve elektronik sözlüklerin Türkçe öğretiminde önemli bir konuma yerleştiğini göstermektedir. 2015 programının ortaokul (5-8.sınıflar) Türkçe dersleri için belirlediği kazanım ve kazanım açıklamaları sözlük kullanımı açısından incelendiğinde aşağıdaki bulgulara ulaşılmıştır:

Tablo 8.

2015 Ortaokul Programındaki Sözlük Kullanımına Dair Tespitler

\begin{tabular}{lll}
\hline $\begin{array}{l}\text { Bölüm } \\
\text { /Alan }\end{array}$ & Sinıf & Kazanım ifadesi \\
\hline Okuma & 5 & $\begin{array}{l}\text { Bir bilgiye veya içeriğe erişmek için basılı ve dijital içeriklerde } \\
\text { içindekiler ve sözlük bölümün kullanmayı bilir. }\end{array}$ \\
\hline Okuma & 5 & $\begin{array}{l}\text { Anlamını bilmediği sözcükleri ve sözcük gruplarını öğrenir. } \\
\text { Sözcükleri öğrenmek için görseller, sözlük, atasözleri ve deyimler } \\
\text { sözlüğ̈̈ vb. araçlar kullanılacaktır. }\end{array}$ \\
\hline Okuma & 6 & $\begin{array}{l}\text { Bir bilgiye veya içeriğe erişmek için basılı ve dijital içeriklerde } \\
\text { içindekiler ve sözlük bölümünü kullanmayı bilir. }\end{array}$ \\
\hline Okuma & 6 & $\begin{array}{l}\text { Anlamını bilmediği sözcük ve sözcük gruplarını anlamını belirler. } \\
\text { Sözcükleri öğrenmek için sözlük, atasözleri ve deyimler sözlüğ̈ vb. } \\
\text { araçlar kullanılacaktır. }\end{array}$ \\
\hline
\end{tabular}




\begin{tabular}{ccl}
\hline Okuma & 7 & $\begin{array}{l}\text { Bir bilgiye veya içeriğe erişmek için basılı ve dijital içeriklerde } \\
\text { içindekiler ve sözlük bölümünü kullanmayı bilir. }\end{array}$ \\
\hline Okuma & 7 & $\begin{array}{l}\text { Anlamını bilmediği sözcük ve sözcük gruplarının anlamını belirler. } \\
\text { Sözcükleri ögrenmek için görseller, sözlük, atasözleri ve deyimler } \\
\text { sözlüğ̈ü, vb. araçlar kullanılacaktır. }\end{array}$ \\
\hline Okuma & 8 & $\begin{array}{l}\text { Bir bilgiye veya içeriğe erişmek için bas1lı ve dijital içeriklerde } \\
\text { içindekiler ve sözlük bölümün kullanmayı bilir. }\end{array}$ \\
\hline Okuma & 8 & $\begin{array}{l}\text { Anlamını bilmediği sözcük ve sözcük gruplarının anlamını belirler. } \\
\text { Sözcükleri ögrenmek için görseller, sözlük, atasözleri ve deyimler } \\
\text { sözlüğ̈u, vb. araçlar kullanılacaktır. }\end{array}$ \\
\hline
\end{tabular}

2015 Türkçe dersi öğretim programı ilkokul ve ortaokuldaki öğretim sürecini birlikte ele almaktadır. Programın sözlük kullanmaya yönlendiren kazanımların okuma alanında toplandığı görülmektedir. Daha öncede ifade edildiği gibi bu programda dil becerilerinin teknolojik gelişmeleri dikkate alarak öğretmeye önem verilmiş ve buna bağlı olarak basılı sözlüklerin yanında dijital sözlüklerden de yararlanılması hedeflenmiştir. Elektronik ortamlardaki sözlükleri kullanma becerisi, bugünün insanının bilgiye ulaşabilmesinde vazgeçilmezdir. Bunlarla birlikte, her sınıfta hem basılı hem de dijital ortamlarda sözlük kullanımına dair kazanımın olması ve böylelikle günlük yaşam için çok önemli olan bu becerilere derslerde yer verilmesi önemlidir. Dolayısıla 2015 programının bu yönde güncellenmesinin günün gerekliliklerine uygun olduğu açıtıtr.

Bunlarla birlikte, öğrencilerin sözlüklerin içindekiler ve sözlük bölümlerini de kullanması gerektiği vurgulanmaktadır. Okuma becerisi ile ilgili kazanımlar arasında yer verilen sözlük kullanımıyla ilgili kazanımların her sınıfta tekrar etmesi öğrencilerinin bu becerileri alışkanlığa dönüştürmesinin beklenildiğini göstermektedir.

2017 ve 2018 Türkçe dersi öğretim programı (ilkokul ve ortaokul 1-8. sınıflar)

2017 ile 2018 yılında uygulamaya konulan programlar anlayış ve tasarım olarak benzerlik gösterdiğinden sözlük kullanmaya yönlendiren özellikler açısından sadece bugün uygulamada olan 2018 programı incelenmiştir. Söz konusu programlarda, temel beceri olarak 2005 yılından bu yana bilinen temel beceriler için yetkinlikler, ayrıca bilgi ve becerilerle birlikte değer eğitimine de önem verilerek birer başlık altında bu konulara dair yaklaşım açıklanmıştır. Ayrıca söz varlı̆̆ını zenginleştirme, dijital ortamların bilgiye erişme ve üretmedeki rolü önceki programlarla örtüşmektedir. Bu programların bireysel farklılıkları, önceki öğrenmeleri, hayat boyu öğrenmeyi, farklı öğretim yollarını, süreç değerlendirmeyi, aktif ve iş birlikli öğrenmeyi benimsemesi 2005 yılından bu yana sürdürülen öğrenme ve öğretme anlayışının hâlen hâkim olduğuna işaret etmektedir. 2017 ve 2018 programları anılan çerçeve ile Türkçe derslerini dinleme / izleme, konuşma, okuma ve yazma öğrenme alanlarına ayırmıştır.

Tablo 9.

2017-2018 Ortaokul Programındaki Sözlük Kullanımına Dair Tespitler

\begin{tabular}{|c|c|c|}
\hline $\begin{array}{l}\text { Bölüm } \\
\text { /Alan }\end{array}$ & Sinif & Kazanım ifadesi \\
\hline $\begin{array}{l}\text { Dinleme / } \\
\text { İzleme }\end{array}$ & 5 & $\begin{array}{l}\text { Dinlediklerinde/izlediklerinde geçen, bilmediği sözcüklerin anlamını } \\
\text { tahmin eder. } \\
\text { Ögrrencilerin sözcük anlamlarına yönelik tahminleri ile sözlük } \\
\text { anlamlarını karşılaştırmaları sağlanır. }\end{array}$ \\
\hline Okuma & 5 & $\begin{array}{l}\text { Bağlamdan yararlanarak bilmediği sözcük ve sözcük gruplarının } \\
\text { anlamıını tahmin eder. } \\
\text { a) Öğrencilerin tahmin ettikleri sözcük ve sözcük grupların } \\
\text { ögrenmek için görseller, sözlük, atasözleri ve deyimler sözlü̈̆̈̈ vb. } \\
\text { araçları kullanmaları sağlanır. b) Öğrencinin ögrendiği sözcük ve }\end{array}$ \\
\hline
\end{tabular}




\begin{tabular}{|c|c|c|}
\hline & & sözcük gruplarından sözlük oluşturması teşvik edilir. \\
\hline $\begin{array}{l}\text { Dinleme } \\
\text { /İzleme }\end{array}$ & 6 & $\begin{array}{l}\text { Dinlediklerinde/izlediklerinde geçen, bilmediği sözcülklerin anlamını } \\
\text { tahmin eder. } \\
\text { Öğrencilerin sözcük anlamlarına yönelik tahminleri ile sözlük } \\
\text { anlamlarını karşılaştırmaları sağlanır. }\end{array}$ \\
\hline Okuma & 6 & $\begin{array}{l}\text { Bağlamdan yararlanarak bilmediği sözcük ve sözcük gruplarının } \\
\text { anlamını tahmin eder. } \\
\text { a) Öğrencilerin tahmin ettikleri sözcük ve sözcük gruplarını } \\
\text { ögrenmek için görseller, sözlük, atasözleri ve deyimler sözlüğ̈̈ vb. } \\
\text { araçları kullanmaları sağlanır. b) Öğrencinin öğrendiği sözcük ve } \\
\text { sözcük gruplarından sözlük oluşturması teşvik edilir. }\end{array}$ \\
\hline $\begin{array}{l}\text { Dinleme } \\
\text { /İzleme }\end{array}$ & 7 & $\begin{array}{l}\text { Dinlediklerinde/izlediklerinde geçen, bilmediği sözcüklerin anlamını } \\
\text { tahmin eder. } \\
\text { Öğrencilerin sözcük anlamlarına yönelik tahminleri ile sözlük } \\
\text { anlamlarını karşılaştırmaları sağlanır. }\end{array}$ \\
\hline Okuma & 7 & $\begin{array}{l}\text { Bağlamdan yararlanarak bilmediği sözcük ve sözcük gruplarının } \\
\text { anlamını tahmin eder. } \\
\text { a) Öğrencilerin tahmin ettikleri sözcük ve sözcük gruplarını } \\
\text { ögrenmek için görseller, sözlük, atasözleri ve deyimler sözlüğ̈̈ vb. } \\
\text { araçları kullanmaları sağlanır. b) Öğrencinin öğrendiği sözcük ve } \\
\text { sözcük gruplarından sözlük oluşturması teşvik edilir. }\end{array}$ \\
\hline $\begin{array}{l}\text { Dinleme } \\
\text { /İzleme }\end{array}$ & 8 & 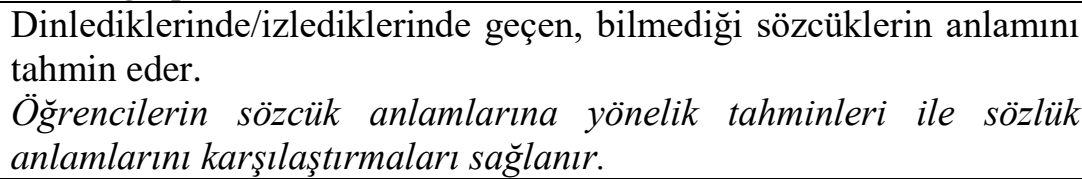 \\
\hline Okuma & 8 & $\begin{array}{l}\text { Bağlamdan yararlanarak bilmediği sözcük ve sözcük gruplarının } \\
\text { anlamını tahmin eder. } \\
\text { a) Öğrencilerin tahmin ettikleri sözcük ve sözcük gruplarını } \\
\text { ögrenmek için görseller, sözlük, atasözleri ve deyimler sözlüğ̈̈ vb. } \\
\text { araçları kullanmaları sağlanır. b) Öğrencinin öğrendiği sözcük ve } \\
\text { sözcük gruplarından sözlük oluşturması teşvik edilir. }\end{array}$ \\
\hline
\end{tabular}

2018 programında ortaokul dinleme / izleme ve okuma alanı kazanımlarında sözcük öğretiminde bağlamdan hareket edilmesi ve tahmine önem verilmesi dikkat çekmektedir. Anlamı tahmin edilen sözcüklerin dinlediğini anlama sürecinde sözlükten, okuduğunu anlama sürecinde ise görseller, sözlük ve atasözü ve deyim sözlüklerinden bulunması istenilmektedir. Ayrıca okuma kazanımları arasında tüm sınıf düzeylerinde sözlük oluşturmanın yer alması ve bu kazanımların tüm sınıf düzeylerinde tekrar etmesi sözlük kullanmanın bir alışkanlığa dönüştürülmesine çalışıldığının kanıtıdır. Dijital ortamların ve medya araçlarının iletişim sürecinde etkin kullanımına ve dijital sözlük kullanmanın ilgili kazanımlarda yer almaması 2015 programı ile bir farklılık oluşturmaktadır. Ancak bu konuda ile ilgili 2018 programının kazanımları arasında da medya metinleri, internet sayfalarının kullanımı gibi önemli kazanım ve açıklamalara rastlanmaktadır. 4. sınıf kazanımlarında yer alan basılı ve dijital sözlük kullanımı kazanımının, üst sınıflarda daha çok genel ă̆ sayfalarının kullanımına yoğunlaşması bu araçların kullanılmayacağı anlamına gelmemekte, aksine daha önce kazanılmış olan bu bilgi edinme becerilerinin elektronik iletişim ortamlarındaki metinleri anlamada kullanılacağını göstermektedir.

Önceki programlarda da yer alan sözlük oluşturma etkinliği sözcük öğrenme ve sözlük kullanmaya alıştırma açısından önemlidir. Sözlük oluştururken sözcüklerle beraber sözcük gruplarının da kapsama alınması ile öğrencilerin sözcüklerin sözlüklerdeki verilişlerine alıştırılmaktadır. Böylece sözlük kullanma konusunda gerçek yaşamda karşılaşılacak durumlara bir hazırlık da yapılmış olacaktır. Yine 2017 ve 2018 programlarında, temalar için önerilen 
konular arasında sözlük kültürünün yer alması, sözlük kullanmanın bilgi, beceri ve alışkanlık boyutu ile birlikte toplumsal yaşamın içinde karşılığının olduğunu ve bir kültürü içinde barındığını açıklamaktadır.

\section{Tartışma ve Sonuç}

Sözcük hazinesinin zenginleşmesi ve bireyin yaşamı için yeterli sözcükle iletişim kurabilmesi için okuma alışkanlığına sahip olması ve anlamını bilmediği sözcükler için de sözlükten yararlanabilmesi zorunludur. Bu beceriler ise, okul döneminde öncelikle okuma ve dinleme öğretimi sürecinde temeli atılan ve dil becerilerinin etkili kullanımı ile geliştirilen bir niteliğe sahiptir. Nitekim söz varlığını zenginleştirme ve bunun için de sözlük kullanma becerilerinin kazandırılması Türkçe dersinin amaçları arasında yer almaktadır. Anlama ve anlatmanın yeterliliğini belirleyen unsurlardan olan sözcüklerin öğrenilmesinde ve hayat boyu devam edecek bir alışkanlığa dönüştürülmesinde sözlük kullanımının yeri büyüktür. Bu amaca istenilen düzeyde ulaşılabilmesi için ise, bu dersin genel çerçevesini ortaya koyan öğretim programlarında çok yönlü ve ihtiyaca cevap verebilen bir planlamanın yapılması gerekir. Bahsedilen gerekçelerle, ortaokul Türkçe öğretim programlarının sözlük kullanmaya yönlendiren özelliklerinin tespit edilmesi amaçlanmıştır. Bu kapsamda aşağıdaki sonuçlara ulaşılmıştır:

1924 lise birinci devre programında, sözlük kullanmaya yönelik herhangi bir hedef ve açıklamanın olmadığı; bununla birlikte 1929, 1931-32 ve 1938 programlarında, sözcüğün anlamını sözlükten buldurmaya dair alıştırmaların yapılması yönünde ders işlenişine dair 1 esas aynı şekilde sürdürülmüştür.

1949 programında, sözlük kullanma imlâ kılavuzu, ansiklopedi, fihrist, harita, plan, indeks gibi ilişkili kaynakların kullanımıyla birlikte ele alınmıştır. $\mathrm{Bu}$ yönde Okuma alanı içerisinde 1 ve İmlâ bölümünde 2 açıklamaya rastlanmaktadır. Böylece öğrencinin bir metni okurken tam olarak anlaması ve gerektiğinde hangi kaynaklardan nasıl yararlanacağını öğrenmesi hedeflenmiştir. Yine programın imlâ bölümündeki açıklamalarda, yeni öğrenilen sözcükler için bir lügat defterinin oluşturulması, hatta ilkokulda bu uygulamaya başlanmasının ve ortaokulda sürdürülmesinin istenilmesi bu davranışın belirli bir sürede alışkanlığa dönüştürülmesinin beklenildiğinin göstergesidir.

1962 programında, önceki programda olduğu gibi sözlük kullanma imlâ kılavuzu, ansiklopedi, fihrist, harita, plan, indeks gibi ilişkili kaynakların kullanımıyla birlikte ele alınmıştır. 1948 programında olduğu gibi, Okuma alanı içerisinde 1 ve İmlâ bölümünde 2 açıklamaya rastlanmaktadır.

1981 programının ortaokul kısmında, ansiklopedi, dizin, dipnot gibi kaynaklardan ve sözlükten bir başvuru eseri olarak yararlanma yeteneğini kazandırmaya dair 1 özel amaç olduğu belirlenmiştir. Önceki programda sözlük ile diğer başvuru kaynaklarından yararlanmak hedefi varken bu programda bu hedef bir yetenek kazandırmaya dönüşerek yer almıştır. Okuma alanında da bu amaç doğrultusunda 6,7 ve 8 . sınıf seviyeleri için 2'şer davranışa yer verildiği görülmüştür. Ayrıca her sınıf düzeyinde sözlükten sadece sözcügün anlamını öğrenmede değil, yazılışı ve dil bilgisel özellikleri için de yararlanılabileceğini göstermek amacıyla, sözlük ile yazım kılavuzuna başvurabilmek şeklinde 1'er davranış ifadesi yer almaktadır. Diğer taraftan, Yöntem bölümünde okuma metni ile ilgili Sözcük Çalışmaları başlığı altında öğretim sürecinde izlenecek yol açıklanmıştır. Bu başlık altında, öğrencinin okunacak metinde karşılaştığ sözcükleri metnin bağlamı içinde kavramadan sözlüğe başvurmaması aksi takdirde ezberciliğe yönlendirilmiş olacağ 1 şeklinde bir ikazın olması da önemli bir bulgudur. Sözcük çalışması bölümünde öğrenciyi ezbere ve kolaycıllğa sevk etmemek için; metni okumadan öğrencinin bilmediği sözcüklere sözlüklerden bakmaması, cümle kurulmaması ve ödev olarak bu sözcüklerin verilmemesi gerektiği vurgulanmıştır.

2006 programında, sözlük kullanma yönelik olarak dinleme/izleme ve okuma öğrenme alanında, söz varlığını zenginleştirme amacına bağlı olarak her iki öğrenme alanı için 3'er kazanım ve açıklamasına yer verilmiştir. Sözlüğe yönlendiren söz konusu kazanımlarda, sözcüklerin metin / bağlam içinde anlamlarının öğrenilmesine, farklı anlamları ile 
kullanılmasına ve öğrenilen sözcüklerden sözlük oluşturmasına önem verildiği görülmektedir. $\mathrm{Bu}$ etkinlik önceki programlarda yer alan sözcük defteri uygulamasının bir devamı olarak görülebilir. $\mathrm{Bu}$ açıdan programın önceki uygulamalardan beslendiği ve sözlük kullanma konusunda bir devamlılık oluşturduğu da belirtilmelidir. Ancak defterden sözlüğe yaşanan değişiklik sözlüğün artık bir kaynak olarak görüldüğü ve onu kullanmanın da bu kaynağın oluşumunu tanıyarak gerçekleşebileceği şeklinde değerlendirilebilir. Sözcük öğrenmede bağlamdan hareket etme, tahmine önem verme ve ön bilgilerden yararlanmanın öne çıkması yapılandırmacılığın bir yansımasıdır. Yaman (2010) ve Melanlığlu'nun (2013) ortaokul öğrencilerinin sözlük kullanma alışkanlığına yönelik çalışmasında ulaşılan sınıf seviyelerine göre sözlük kullanma alışkanlığının arttığına dair sonuç, programın amaçlarına ulaştı̆̆ını düşündürmektedir. Fakat Yaman'ın aynı çalışmasında öğrencilerin \%63'ünün sınıfa sözlük getirmediği, sözlük kullanmaktan hoşlanmadığı ve sözlük kullanmayla etkinliklerin ev ödevi olarak verildiği tespitleri programın sözlük kullanma kazanımlarının yeterince öğrenciye aktarılmadığını da göstermektedir. Programda elektronik sözlüklerin kullanılmasına yönelik kazanımların olmayışı, dijital çağda yaşadığımız düşünüldüğünde bir eksikliktir. Türkçe Sözlük dışında atasözleri ve deyimler sözlügü̈, terimler sözlüğ̈, ansiklopedik sözlük vb. den yararlanılmasının istenilmesi öğrenciyi sözlük kullanırken farklı ve alternatif kaynaklara sevk etmektedir. Bunlarla birlikte, programdaki sözlüğe yönlendiren kazanımlar içerisinde etkinlik örneklerine rastlanması, hazırlanacak okul sözlüklerinin ders kitapları ve sürecini dikkate alması gerektiğini vurgulamaktadır. Göçer'e (2009) göre de, hazırlanacak sözlüklerin düzeye uygun olması ve ders kitaplarıyla eşgüdüm içerisinde hazırlanması gerektiği görüşü programın kazanımları ile uyuşmaktadır. 2005 ilkokul programında olduğu gibi 2006 ortaokul programının sonunda da kısa bir sözlüğün yer alması, bir yenilik olması nedeniyle önemlidir.

2015 programında ortaokul kademesi için, sözlük kullanmaya yönlendiren kazanımlar okuma alanında toplanmıştır. Sözlük kullanmaya yönelik her sınıf seviyesinde 2 farklı kazanım ve açılaması yer almıştır. Daha öncede ifade edildiği gibi bu programda dil becerilerinin öğretiminde teknolojinin etkin kullanımı önemsenmiş, basılı sözlüklerin yanında dijital sözlüklerden de yararlanılması hedeflenmiştir. Buna uygun olarak, her sınıfta hem basılı hem de dijital ortamlarda sözlük kullanımına dair kazanımın olması ve günlük yaşam için çok önemli olan bu becerilere derslerde yer verilmesi ihtiyaca cevap veren bir yeniliktir. Dolayısıyla, 2015 programının bu özellikleri ile günün gerekliliklerini karşılamayı hedeflediği açıktır. 2006 programında olduğu gibi bu program da, Maden ve diğerlerinin (2017) de belirttiği gibi, sözcük öğretiminde Türkçe sözlükle birlikte atasözü ve deyimler sözlüğü, terim sözlüğü ve görsellerden, aynı kavram alanına giren sözcüklerden yararlanmanın tavsiye edildiği görülmektedir. Yine okuma alanındaki 2 kazanımın her sınıfta tekrar etmesi, sözlük kullanımıyla ilgili becerilerin alışkanlığa dönüştürülmesinin beklendiğini göstermektedir. Baskın'ın (2017) yapmış olduğu araştırmada ulaşılan okul sözlüklerinin hitap ettiği kullanıcıların yani öğrencilerin ihtiyaçlarını karşılayacak düzeyde olmadığı tespiti programın sözlük kullanmaya dair amaçlarının sözlük hazırlayıcıları tarafından dikkate alınmadığını ortaya koymaktadır. Bunun yanında Baskın aynı araştırmada, okul sözlükleri hazırlanırken Türkçe dersi etkinlikleri ve programın amaç ve ilkelerinin dikkate alınması gerektiği görüşü bu açıdan yol göstericidir.

2018 programında ortaokul kademesi için, sözlük kullanmaya yönelik kazanımlar dinleme/izleme ve okuma alanlarında yer almıştır. Bu doğrultuda 5, 6, 7 ve 8 . sınıf düzeylerinde sözlük oluşturmanın, her alan için 1 olmak üzere, 2'şer kazanım ile yer bulması ve tekrar etmesi sözlük kullanmanın bir alışkanlığa dönüştürülmesine çalışıldığının kanıtıdır. Bunlarla birlikte, önceki programlarda yer alan sözlük oluşturma etkinliğinin bu programda da devam ettiği görülmektedir. Ancak sadece sözcüklerin değil sözcük gruplarının sözlüklerde yer almasının istenilmesi, sözlüğün yapısına ve nasıl kullanılacağına dair öğrencilerin alıştırılmaya çalışılması ile açıklanabilir. Yine hem 2017 hem de 2018 programlarında temalar için önerilen konular arasında Sözlük Kültürü başlığının yer alması önemli bir bulgudur. Bu bulgu programda, sözlük kullanmanın bilgi, beceri ve alışkanlık boyutu ile birlikte toplumsal yaşamın içinde karşılığının olduğunu ve bir kültürü içinde barındığını ifade etmektedir. Kaplan ve Yıldız'ın (2018) 
elektronik sözlük kullanma alışkanlığına yönelik araştırmasında, ortaokul öğrencileri esözlükleri basılı sözlüklere göre hızlı ve kullanışlı bulduğu tespit edilmiştir. Ayrıca Maden ve Maden'in (2018) Türkçe öğretmeni adaylarının elektronik sözlük ve yazım kılavuzu kullanma alışkanlıkları ile ilgili araştırmasında da, adayların çoğunluğunun e-sözlük ve yazım kılavuzu kullandığ 1 tespit etmiştir. Bu nedenle teknolojik gelişmelerin sözlük kullanma alışkanlığına yön verdiği açıkça ortadır. Öğrencilerin ve yetişkinlerin yaşam koşullarına koşut biçimde dijital araç ve ortamları daha iyi kullandıkları ve klasik yollara göre tercih ettikleri de bilinmektedir. Buna karşın 2018 programında, sözlük kullanmaya yönelik kazanımlarda dijital sözlüklerin 2015 programının aksine yer almaması bir eksiklik olarak görülmektedir.

Sonuç olarak, 1924'ten 2018 yılına kadar uygulamaya konulan ortaokul ikinci kademe programlarında, sözlük kullanmaya yönelik hedef ve açıklamaların genel olarak okuma alanında yoğunlaştı̆̆ 1 , 2006 programından sonra ise dinleme/izleme ve okuma alanları arasında bütünlük içinde planladığı görülmüştür. Bunların yanında 1949 ve 1962'de imla, 1981 programında ise dil bilgisi davranış ve açıklamalarında sözlük kullanımından bahsedildiği de belirtilmelidir. Sonuç itibarıyla, ortaokul kademesi için sözlük kullanımının 1981 programından itibaren sınıf düzeyi dikkate alınarak daha ayrıntılı ve öğretim sürecini planlayacak biçimde amaç ve açıklamalarda yer bulduğu söylenebilir.

\section{Öneriler}

Araştırma sonuçlarından hareketle, Türkçe dersi öğretim programları ile ilgili olarak şu öneriler sunulabilir:

- Sözlük kullanımına yönelik amaç ve kazanımların ders kitaplarında karşılığının olmasına önem verilmelidir.

- Sözlük kullanımı ile ilgili açıklama ve kazanım ifadelerinin okuma ile birlikte tüm öğrenme alanları içinde yer bulması sağlanmalıdır.

- Konuya uygun türde (eş zit anlamlılar, kavramlar, isimler, terimler sözlüğü gibi) ve seviyeye uygun okul sözlüklerinin kullanımına özen gösterilmelidir.

- Basılı sözlüklerle birlikte dijital sözlüklerin de derslerde kullanımına yer verilmelidir. FATIH projesinin getirilerinden olan akıllı tahta ve internet kullanımı bunu kolaylaştırmaktadır. Dijital sözlük kullanımında öğrencinin ilgisini çekebilecek esözlük, mobil sözlük ve sesli sözlük vb. farklı uygulamalara başvurulmalıdır.

- Sözlüğe karşı öğrencinin olumlu tutum kazanmasını sağlayıcı etkinliklerin artırılması sağlanmalıdır.

- Sözlük kullanma konusunda, ortaokul öğrencileri için Türkçe öğretmenleri hem öğrenmelerine rehber hem de kullanmalarına örnek olmalıdır.

- Ders kitaplarındaki sözlük kullanmaya dair etkinlikler ev ödevi olarak verilmemelidir.

\section{Kaynaklar}

Aksan, D. (2007). Her yönüyle dil ana çizgileriyle dil bilim. Ankara: Türk Dil Kurumu Yayınları.

Arı, G. (2006). Sözcük öğretimi. C. Yıldız (Yay. haz.). Kuramdan Uygulamaya Türkçe Öğretimi içinde (ss.311-313). Ankara: PegemA Yayıncılık.

Baskın, S. (2017). 5. sınıf öğrencilerinin sözlük ihtiyacı ve ortaokul sözlükleri. Türkiye Sosyal Araştırmalar Dergisi, Aralık, 765-789.

Boz, E. ve Demirtaş, A.A. (2011), Türkçe öğretmenlerinin okul sözlüğü kullanma konusundaki tutum ve davranışları. Dil ve Edebiyat Araştırmaları Dergisi, 3, 65-134.

Budak, Y. (2000). Sözcük öğretimi ve sözlüğün işlevi. Dil Dergisi, 92, 19-26.

Can, A. ve Deniz, E. (2016). Ortaöğretim öğrencilerinin sözlüklere yönelik tutumları. Millı̂ Eğitim Dergisi, 210, 320-336.

Dağtaş, A. (2014). Ortaokul 7. sınıf öğrencilerinin elektronik sözlüklere yönelik görüşleri. The Journal of Academic Social Science, 2(7), 542-555. 
Demir, C. (2006). Türkçe/edebiyat eğitimi ve kişisel sözcük serveti. Millî Eğitim Dergisi, 34(169).

Ekiz, D. (2009). Bilimsel araştırma yöntemleri. Ankara: Anı Yayıncılık.

Elbir, B. ve Yıldız, H. (2014). Türkçe öğretiminde sözlük kullanımı ve sözlükçülük. Adıyaman Üniversitesi Sosyal Bilimler Enstitüsü Dergisi, 2013(11), 249-268.

Göçer, A. (2001). Türk dili ile ilgili sözlüklere genel bir bakış ve günümüz ilköğretim sözlükleri. Türk Dili, 598, 388-403.

Göçer, A. (2009). Türkçe eğitiminde öğrencilerin söz varlığını geliştirme etkinlikleri ve sözlük kullanımı. Turkish Studies International Periodical For the Languages, Literature and History of Turkish or Turkic 4(4),1025-1055.

İbe Akcan, P. (2012). Türkçe öğretiminde sözlük kullanımı: Türkçe çalışma kitaplarında sözlüğe gönderen alıştırmalar. M. Aksan ve Y. Aksan (Yay. haz.). Türkçe Öğretiminde Güncel Çalı̧̧malar içinde (ss.93-102). Ankara: Şafak Yay.

İlhan, N. (2009). Sözlük hazırlama ilkeleri, çeşitleri ve özellikleri. Turkish Studies International Periodical For the Languages, Literature and History of Turkish or Turkic 4(4),534-554.

Karadağ, Ö.(2011). İlköğretim Türkçe sözlüklerinin hazırlanmasında temel ölçütler. Türklük Bilimi Araştırmaları Dergisi, 30, 193-207.

Kaplan, T. ve Yıldız, F. (2018). Ortaokul öğrencilerinin elektronik sözlük kullanımına yönelik görüşleri. Ulakbilge, 6(20), 101-112.

Kocaman, A. (1998). Dilbilim, sözlük, sözlükçülük. Kebikeç, 6, 111-113.

Kolaç, E. (2009). Öğretmen adaylarının Türkçe sözlük ve yazım kılavuzu kullanma konusundaki tutum ve görüşleri. Türk Dili, 691, 50-60.

Korkmaz, Z. (2010). Gramer terimleri sözlüğ̈̈. Ankara: Atatürk Kültür, Dil ve Tarih Yüksek Kurumu Yayınları.

Maden, S., Demir, R. ve Maden, A. (2017). Türkçe ders kitaplarındaki söz varlığının öğrenci etkinliklerine yansiması. International Journal of Language Academy 5(3), 235-251.

Maden, S. ve Maden, A. (2018). Türkçe öğretmeni adaylarının elektronik sözlük ve yazım kılavuzu kullanma alışkanlıkları. Kırıkkale Üniversitesi Sosyal Bilimler Dergisi (KÜSBD), 8(2), 377-396.

Melanlığlu, D. (2013). Ortaokul öğrencilerinin sözlük kullanma alışkanlıkları: Nitel bir araştırma. Uluslararası Türkçe Edebiyat Kültür Ĕ̈itim (TEKE) Dergisi, 2(2), 266-284.

Merriam, S. (1998). Qualitative research and case study applications in education. Revised and expanded from case study research in education. USA: JB Printing.

Millî Eğitim Bakanlığı (2005). İlköğretim Türkçe dersi öğretim programı (1-5. Sinıflar). Ankara.

Millî Eğitim Bakanlığı (2006). İlköğretim Türkçe dersi öğretim programı (6-8. Sinıflar). Ankara.

Millî Eğitim Bakanlığı (2015). Türkçe Dersi (1-8.sinıflar) öğretim programı. Ankara.

Millî Eğitim Bakanlığı (2017). Türkçe Dersi öğretim programı (ilkokul ve ortaokul 1-8.sinıflar). Ankara.

Millî Eğitim Bakanlığı (2018). Türkçe Dersi ögretim programı (ilkokul ve ortaokul 1-8.sinıflar). Ankara.

Özbay, M. ve Melanlığlu, D. (2013). Türkçe öğrenen yabancıların sözlük kullanma becerileri üzerine bir araştırma. Ana Dili Ĕgitimi Dergisi, 1(1), 13-23.

Özbek, A. B. ve Ergül, C. (2018). İlkokul 4. sınıf Ders Kitaplarının Okunabilirliklerinin Değerlendirilmesi. Mersin Üniversitesi Ĕ̈itim Fakültesi Dergisi, 14(2), 653-668.

Sever, S. (2000). Türkçe Öğretimi ve Tam Öğrenme. Ankara: Anı Yayıncılık.

Süt, M. (2015). Ortaokul Türkçe dersinde ögrretmen ve öğrencilerin Türkçe sözlük kullanma tutumları. (Yayımlanmamış yüksek lisans tezi). Fırat Üniversitesi Eğitim Bilimleri Enstitüsü, Elazığ.

Temizyürek, F. ve Balc1, A. (2006). Cumhuriyet dönemi ilköğretim okulları Türkçe programları. Ankara, Nobel Yayınları.

Türk Dil Kurumu (2009). Türkçe sözlük (10. Baskl). Ankara: TDK Yayınları. 
Vardar, B. (2003). Açıklamalı dilbilim terimleri sözlüğü. İstanbul: Multilingual Yayınları.

Yaman, H. (2010), İlköğretim ikinci kademe öğrencilerinin sözlük kullanma alışkanlıkları üzerine bir değerlendirme. Türklük Bilim Araştırmaları Dergisi, 27, 735-751.

Yaman, H. ve Dağtaş, A. (2014). Ortaokul 6, 7 ve 8. sınıf öğrencilerinin sözlüklere yönelik tutumları: betimsel bir analiz. Turkish Studies- International Periodical for theLanguages, Literature and History of Turkish or Turkic, 9(3), 1581-1597.

Yıldırım, A. ve Şimşek, H. (2013). Sosyal bilimlerde nitel araştırma yöntemleri. Ankara: Seçkin Yayıncilik.

\section{Extended Abstract}

\section{Introduction}

Language is the most effective way of expressing our feelings and thoughts. However, the ability of language to convey emotions and thoughts fully and effectively to the other side depend on having a proper and adequate vocabulary. The preservation of the words and words of the language and the acquisition of language in process of language teaching are important and priority subjects. Words are among the oldest and most important tools of language learning. So, dictionaries with all the words of the language should be prepared and used carefully. Indeed, knowing the language is equivalent knowing the word. Even the list of the word, ie dictionaries, have been memorized to the learners. In addition to the widespread acceptance of what people think in words, the dictionary seems to be an effective tool in language learning. It is possible to classify dictionaries in different ways depending on the registration status of the products they process, the environment where they are created, the purpose of creation and the way they are written. The dictionaries prepared for use in the learning process in schools are called the school dictionary. Students must always keep their dictionaries available when they attempt to understanding effort of a text. Using the dictionary provides the students with the versatile benefits of expressing the meaning of the words that they need in verbal and written communication, including the ability to express themselves in confidence, overcoming the difficulties of communication, seeing what functions and how words go in for in the daily language. These benefits lead students to use dictionary and provide to turning into habit in time. In order to reach these benefits, an environment which is appropriate to the level and needs of the students should be provided in the process of teaching mother tongue. In other words, in order to gain the skills of using dictionary, it is possible to say that firstly, it is necessary to make important plans such as revealing the purpose in the programs, explaining how to benefit from the source in the process of teaching and learning and raising the teachers well. From the point, it should be expected that in our country Turkish course curriculum and textbooks are sufficient in terms of the usage of dictionaries and also that teachers should have awareness and competence about the importance of benefiting from the dictionary. In Turkish courses, it is vital to gain the ability of utilization from dictionary among the goals related to the teaching of words. This habit determines not only the success of the school, but also the level of understanding and expression of the individual in later life. In other words, words play a key role in both their studentship and adulthood for the individuals to understand the texts they read, and the speeches they listen to completely and accurately and also to tell the thoughts dealing with what they understand. The word reservoir of individuals who gain the habit of using the dictionary are enriched. According to this, they express themselves better. They communicate with surroundings healthier. The habit of using the dictionary is intensively acquired in Turkish courses through Turkish curriculum. There is a need for a dictionary to learn unknown words within the text in reading studies in Turkish lessons. The most effective way to improve the vocabulary of our children is without a doubt to give them the habit of reading, and to make them a natural requirement to apply to dictionaries as a reference book while reading. Because there is a complementary link between the vocabulary and reading. To what extent the text read will be understood depends on the richness of the vocabulary. This also applies to success in other language skills. When the related field is 
examined in the literature, it is seen that the Turkish curriculum which plans the teaching process to gain the habit of using dictionary has not been evaluated in this respect. It has been predicted that to study Turkish education programmes prepared for secondary school in accordance with the findings from dictionary using skills aspect will be beneficial for the analysis of the fact relating to the subject. So, this study has been carried out to contribute such as seeing and evaluating in a chronological way how dictionary using habits are adopted programmatically, showing how it has been changed and progressed from the beginning of the programmatical education to now, leading the way to the studies which will be carried out about the subject in the future.

\section{Method}

In this study, qualitative research approach has been adopted. The study is limited with explanations, principles and target expressions which are detected in the second grade Turkish courses prepared from the Republic to the present day, conduct to the dictionary and suggest and encourage using dictionary. Document analysis technique has been used for collecting research data. The programs that are the data source of the study were examined separately for the use of dictionary and the purpose and explanation statements were determined and classified according to the program titles. Expressions that directly support the use of dictionaries by the students or that contribute to making the use of the dictionary a habit are gathered under the relevant section of each program and subjected to content analysis. Expressions related to the use of the dictionary were interpreted by evaluating according to the learning area and class level.

\section{Result and Discussion}

The principles, explanations and target expressions related to the use of dictionary in the secondary level programs are generally collected in the field of reading skill. With the 2005 programme, preparing dictionary using skills with the spiral structure and make them face students with different class levels, from adopting dictionary using habit aspect is one of the valuable indications. Increasing the content related to dictionary usage from past to present has been seen in the programs. When we look at he general objectives of the first Turkish programs of the Republic period and their explanations about using dictionary, it is understood that the teacher is in the center of program. It was determined that there was a significant increase in the number of behaviors related to using dictionary in the Turkish language in 1981 with 1949 secondary school Turkish programs. With the 2005 elementary and 2006 secondary Turkish programmes based in the constructivity approach, it has been detected that activities relating education has been included and functions which center students and turn dictionary using into a skill has been prepared. It can be said that the maximum gain for using dictionary is included in these two programs and this is an indication of the importance given to using dictionary. The 2015 and 2017-2018 Turkish programs aim to provide the students with the ability to use the dictionary in a helical structure. Besides, with the technological developments, functions, relating electronical Turkish dictionary using habits has been deducted in Turkish programmes over 2006. The increase in the content related to the use of the dictionary due to technological developments shows that current developments and social needs are important. The word book activity in secondary school Turkish programs has changed in the form of dictionary creation in Turkish programs prepared in recent years and it is seen as the most concrete application which has continuity in the use of the dictionary. 